\title{
Effects of Planting Depth on Landscape Tree Survival and Girdling Root Formation
}

\author{
Christina Wells, Karen Townsend, Judy Caldwell, Donald Ham, E. Thomas Smiley, and \\ Michael Sherwood
}

\begin{abstract}
Landscape trees are frequently planted with their root collars below grade, a practice that may predispose them to transplant failure and girdling root formation. The objective of the present research was to examine the effect of planting depth on the health, survival, and root development of two popular landscape trees, red maple (Acer rubrum) and Yoshino cherry (Prunus $\times$ yedoensis). Trees were transplanted with their root flares at grade, $15 \mathrm{~cm}(6 \mathrm{in})$ below grade, or $31 \mathrm{~cm}$ (12 in) below grade. Deep planting reduced the survival of Yoshino cherries: 2 years after transplant, $50 \%$ of the $15 \mathrm{~cm}$ (6 in) and $31 \mathrm{~cm}$ (12 in) deep-planted cherries had died, whereas all the cherries planted at grade had survived. Survival of maples was not affected by planting depth. Deep planting also influenced the development of girdling roots. Three years after transplant, maples planted at grade had $14 \%$ of their trunk circumference encircled by girdling or potentially girdling roots; this number rose to $48 \%$ and $71 \%$ for $15 \mathrm{~cm}(6 \mathrm{in})$ and $31 \mathrm{~cm}(12 \mathrm{in})$ deep-planted maples, respectively. There were no treatment-related differences in girdling root development in the cherries. These results are consistent with arborists' observations that deep planting is a significant source of stress in landscape trees.
\end{abstract}

Key Words. Acer rubrum; girdling root; planting depth; Prunus $\times$ yedoensis.

Root collar burial is remarkably common in landscape trees. In a 1991 survey, 93\% of professionally planted trees had root collars obscured by soil or mulch, and the extent of this deep planting was seldom less than 2 in (Smiley and Booth 2000). In a survey conducted by the University of Rhode Island's Sustainable Landscape Arboretum, buried root collars were present in over $75 \%$ of the nursery-grown trees examined, and the depth of burial ranged from 3 to 12 in (Maynard 1995).

Root collar burial at transplant positions much of the tree's root system in deeper soil layers where access to water, nutrients, and oxygen may be restricted. Anecdotal evidence suggests that root collar burial predisposes trees to transplant failure and girdling root development, but little scientific research has been performed to evaluate these claims. A study on pygmy date palm suggests that deep planting reduces growth and survival in this species (Broschat 1995), and similar results have been reported for willow oak (Quercus phellos) and white pine (Pinus strobus; Smiley and Booth 2000). Recent work by Gilman and Grabosky (2004) indicates that deep-planted trees may fail to intercept water from light rainfall events soon after transplant, leading to significant water stress. Nonetheless, the general significance of deep planting as a source of landscape tree stress remains open for debate.
The objective of the present research was to examine the effect of planting depth on the health, survival, and root development of two popular landscape trees, red maple (Acer rubrum) and Yoshino cherry (Prunus $\times$ yedoensis). A combination of above- and below-ground measurements was used to characterize tree responses to root collar burial.

\section{METHODS}

\section{Experimental Planting}

The experiment was performed in a half-acre open field in the Roland Schoenike Arboretum in Clemson, South Carolina, U.S. The site exhibited a $10 \%$ slope. The soil was an eroded Cecil sandy loam with a $\mathrm{pH}$ of 5.5, a cation exchange capacity of $3.9 \mathrm{meq} / 100 \mathrm{~g}$, and sufficient levels of all mineral nutrients except phosphorus, which was present at $5.6 \mathrm{~kg} / \mathrm{ha}$ $(5 \mathrm{lb} / \mathrm{ac})$.

In December 1996, 2 in caliper balled-and-burlapped 'October Glory' red maples (Acer rubrum) and Yoshino cherries (Prunus $\times$ yedoensis) were obtained from a local nursery. The trees had been grown from cuttings on their own root stock and were dug immediately before transplant. Thirty trees of each species were planted in a randomized complete block design consisting of ten replicate blocks within which the two species and three planting depth treatments were randomly arranged. Planting depths included control (planted with the 
root flare at grade), $15 \mathrm{~cm}$ (6 in) deep-planted (planted with the root flare $15 \mathrm{~cm}$ below grade), and $31 \mathrm{~cm}$ (12 in) deepplanted (planted with the root flare $31 \mathrm{~cm}$ below grade). Replicate blocks were laid out as rows perpendicular to the direction of the slope.

Planting holes were dug with a backhoe to roughly twice the width of the root ball. After installation, the planting holes were refilled by hand using original, unamended soil. Newly planted trees were mulched to the canopy edge, and followup care consisted of weed control within the mulched rings. No supplemental irrigation or fertilization was applied.

\section{Measurement Schedule}

In May 1997, 6 months after transplant, mean shoot length was measured by averaging the lengths of three randomly selected primary lateral shoots collected at a height of 1.8 to $3 \mathrm{~m}$ (6 to $10 \mathrm{ft}$ ) above the ground. Mean leaf chlorophyll content was estimated by averaging SPAD meter readings from four randomly selected leaves per tree (Minolta SPAD502; Minolta Inc., Tokyo, Japan). Mean individual leaf area was measured by averaging the areas of 10 randomly selected leaves per tree (LI-3100 leaf area meter, Li-Cor Biosciences, Lincoln, NE).

At the same time, trees were visually rated by a panel of four tree professionals. Panelists scored each tree for shoot tip dieback, defoliation, chlorosis, and leaf curl. The severity of each condition was scored on a scale of 0 to 3 , with a score of 0 indicating that the condition was not present and a score of 3 indicating that the condition was severe. Scores from all panelists were averaged to produce a set of mean scores for each tree.

In December 1997, one year after transplant, 4 soil cores $\left(5.1 \mathrm{~cm}^{2}\right.$ [0.82 in $]$ in diameter, $61 \mathrm{~cm}$ [24 in] deep) were obtained from beneath each tree to measure the root mass density (RMD; g root dry weight $/ \mathrm{cm}^{3}$ soil volume) and depth distribution of the root system. Two cores were taken $15 \mathrm{~cm}$ (6 in) from the trunk (i.e., within the diameter of the original root ball), and two cores were taken $41 \mathrm{~cm}$ (16 in) from the trunk (i.e., outside the diameter of the original root ball). Each core was divided into two depth increments of $30.5 \mathrm{~cm}$ (12 in) each.

Roots (less than $5 \mathrm{~mm} / 0.2$ in diameter) from each depth increment were sieved free of soil and oven-dried for 2 days at $70^{\circ} \mathrm{C}\left(158^{\circ} \mathrm{F}\right)$. For each core, RMD was calculated for the individual depth increments and for the core as a whole. The root depth ratio (RDR) for each core was calculated as the RMD of the upper depth increment divided by the RMD of the lower depth increment.

In January 2000, 3 years after transplant, an air compressor with an attached Air Spade ${ }^{\mathrm{TM}}$ (Concept Engineering Group, Inc., Verona, PA) was used to expose the root collars of all remaining trees to assess girdling root development. Girdling roots were defined as woody roots that contacted and en- circled a portion of the stem causing bark and wood compression (Johnson and Hauer 2000). Potentially girdling roots were defined as woody roots that crossed within $2.5 \mathrm{~cm}$ (1 in) of the stem in a girdling orientation. The percentage of the trunk circumference encircled by girdling and potentially girdling roots was recorded for each tree.

Tree survival data were analyzed by $\chi^{2}$. All other data were analyzed in SAS (SAS Software, Inc., Cary, NC) using PROC GLM; mean separations were performed with Tukey's HSD. Treatment main effects and dependent multiple comparisons were evaluated at the $\alpha=0.05$ significance level. Because girdling root data were expressed as percentages, they were arsine transformed before analysis.

\section{RESULTS}

\section{Tree Survival}

Deep planting had a strong negative effect on the survival of Yoshino cherries. Two years after transplanting, 50\% of the $15 \mathrm{~cm}$ (6 in) and $31 \mathrm{~cm}$ (12.4 in) deep-planted cherries had died, whereas all the control cherries had survived (Figure 1). The majority of these deaths occurred during the second growing season after transplant (i.e., 1998). Survival of maples was not affected by planting depth: mortality among the treatment groups varied from $0 \%$ to $10 \%$ and did not differ significantly with treatment (Figure 1). After 2 years, no further tree mortality was observed in either species.

\section{Above-Ground Measurements}

In May 1997, 6 months after transplant, there were no treatment-related differences in the lengths of individual shoots or the areas of individual leaves for either species. However, 31 $\mathrm{cm}$ (12.4 in) deep-planted trees of both species had significantly lower leaf chlorophyll content as estimated by SPAD meter readings (Table 1). None of the maples showed visible signs of stress at this time, but the $31 \mathrm{~cm}$ (12.4 in) deepplanted cherries were rated significantly higher than the controls for defoliation, chlorosis, and leaf curl (Table 1).

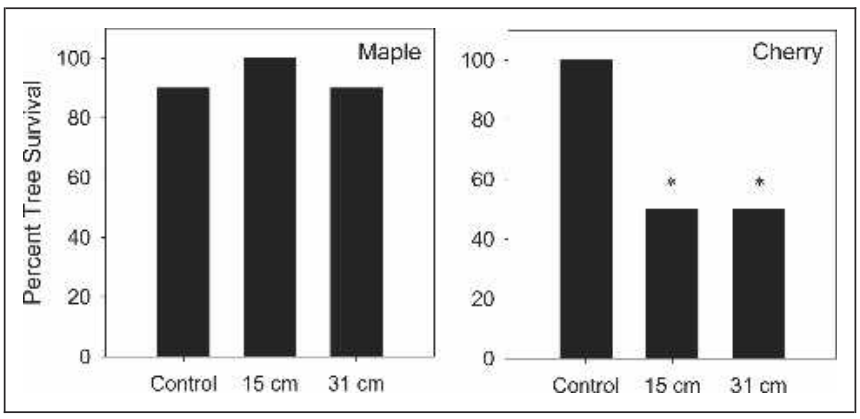

Figure 1. The percentage of trees from control, $15 \mathrm{~cm}(6$ in) deep-planted, and $31 \mathrm{~cm}$ (12.4 in) deep-planted treatment groups that survived more than 2 years after transplant. Within a panel, bars marked with an asterisk are significantly different from control $\left(P<0.001 ; \chi^{2}\right.$ test). 
Table 1. Mean values for above-ground measurements and visual ratings taken 6 months after transplant (May 1997) and root measurements taken 12 months after transplant (December 1997).

\begin{tabular}{|c|c|c|c|c|c|c|}
\hline & \multicolumn{3}{|c|}{ Maple } & \multicolumn{3}{|c|}{ Cherry } \\
\hline & Control & $15 \mathrm{~cm}$ & $31 \mathrm{~cm}$ & Control & $15 \mathrm{~cm}$ & $31 \mathrm{~cm}$ \\
\hline \multicolumn{7}{|l|}{ Measurements } \\
\hline Shoot length $(\mathrm{cm})$ & $4.9 \mathrm{a}$ & $6.3 \mathrm{a}$ & $4.8 \mathrm{a}$ & $13.2 \mathrm{a}$ & $13.7 \mathrm{a}$ & $14.7 \mathrm{a}$ \\
\hline SPAD meter reading & $36.1 \mathrm{a}$ & $36.2 \mathrm{a}$ & $34.0 \mathrm{~b}$ & $37.1 \mathrm{a}$ & $35.7 \mathrm{ab}$ & $34.5 \mathrm{~b}$ \\
\hline Individual leaf area $\left(\mathrm{cm}^{2}\right)$ & $35.4 \mathrm{a}$ & $35.2 \mathrm{a}$ & $36.7 \mathrm{a}$ & $10.7 \mathrm{a}$ & $11.8 \mathrm{a}$ & $11.5 \mathrm{a}$ \\
\hline Root mass density $\left(\mathrm{mg} / \mathrm{cm}^{3}\right)$ & $1.8 \mathrm{a}$ & $1.9 \mathrm{a}$ & $1.5 \mathrm{a}$ & $1.1 \mathrm{a}$ & $1.1 \mathrm{a}$ & $0.8 \mathrm{a}$ \\
\hline Root depth ratio ${ }^{y}$ & $2.6 \mathrm{a}$ & $1.4 \mathrm{ab}$ & $0.6 \mathrm{~b}$ & $4.1 \mathrm{a}$ & $1.9 \mathrm{~b}$ & $1.7 \mathrm{~b}$ \\
\hline \multicolumn{7}{|l|}{ Visual Ratings (0 to 3 scale $)^{x}$} \\
\hline Shoot tip dieback & $1.5 \mathrm{a}$ & $1.3 \mathrm{a}$ & $1.3 \mathrm{a}$ & $0.4 \mathrm{a}$ & $0.7 \mathrm{a}$ & $0.9 \mathrm{a}$ \\
\hline Defoliation & $0 \mathrm{a}$ & $0 \mathrm{a}$ & $0 \mathrm{a}$ & $0.8 \mathrm{a}$ & $1.3 \mathrm{ab}$ & $1.6 \mathrm{~b}$ \\
\hline Poor leaf color & $0.1 \mathrm{a}$ & $0.1 \mathrm{a}$ & $0.1 \mathrm{a}$ & $1.25 \mathrm{a}$ & $1.8 \mathrm{ab}$ & $2.1 \mathrm{~b}$ \\
\hline Leaf curl & $0 \mathrm{a}$ & $0 \mathrm{a}$ & $0 \mathrm{a}$ & $1.4 \mathrm{a}$ & $2.1 \mathrm{ab}$ & $2.4 \mathrm{~b}$ \\
\hline
\end{tabular}

${ }^{\mathrm{z}}$ Within a row and species, treatment means followed by different letters are significantly different at $P<0.05$.

${ }^{\mathrm{y}}$ Values averaged across both distances from the trunk, i.e., $15 \mathrm{~cm}(6 \mathrm{in})$ and $41 \mathrm{~cm}(16 \mathrm{in})$.

${ }^{\mathrm{x}} 0=$ condition is not present; $3=$ condition is severe.

\section{Root Mass Density and Distribution}

In December 1997, 1 year after transplantation, the maples had significantly higher RMDs than the cherries $(1.75 \pm 0.98$ versus $1.02 \pm 0.81 \mathrm{mg}$ root $\mathrm{cm}^{-3}$ soil; $P<0.0001$; Tables 1 and 2), but planting depth treatments had no effect on RMD. There was a strong effect of distance from the trunk: RMD within the diameter of the original root ball was twice as great as that outside the root ball $(1.83 \pm 1.06$ versus $0.95 \pm 0.61$; $P<0.0001$ ), and this difference was particularly marked in the maples (distance*species $P<0.0545$ ).

Although planting depth had no effect on the total mass of roots present in the top $61 \mathrm{~cm}$ (24 in) of soil, it had a strong effect on the depth distribution of this root mass (Figure 2; Tables 1 and 3). Within the original root ball diameter, the RDR (see "Methods") of maples planted at grade was $3.05 \pm$ 2.41. This indicates that the root mass per cubic centimeter of soil was approximately three times greater in the upper 30.5 $\mathrm{cm}$ (12 in) of soil than in the lower 30.5 to $61 \mathrm{~cm}$ (12 to 24 in) soil depth. RDR declined markedly with planting depth to

Table 2. Effect of planting depth treatment $(0,15$, or 31 $\mathrm{cm}(0,6$, or $12 \mathrm{in})$ deep-planted), distance from the trunk (15 or $41 \mathrm{~cm}$ (6 or $16 \mathrm{in})$ ), and species (maple or cherry) on the root mass density ( $\mathrm{g}$ root $\mathrm{cm}^{-3}$ soil) in the top $60 \mathrm{~cm}$ (24 in) of soil.

\begin{tabular}{llcr}
\hline Source of variation & DF & F Value & Pr $>F$ \\
\hline Treatment & 2 & 1.30 & 0.2780 \\
Distance & 1 & 38.48 & $<0.0001$ \\
Treatment*distance & 2 & 2.04 & 0.1351 \\
Species & 1 & 27.18 & $<0.0001$ \\
Treatment*species & 2 & 0.06 & 0.9437 \\
Distance*species & 1 & 3.78 & 0.0545 \\
Treatment*distance*species & 2 & 0.75 & \\
\hline
\end{tabular}

${ }^{\mathrm{z}}$ Measurements were taken in December 1997, 1 year after transplant.
$1.09 \pm 0.45$ for $15 \mathrm{~cm}$ ( 6 in) deep-planted maples and $0.36 \pm$ 0.19 for $31 \mathrm{~cm}$ (12 in) deep-planted maples. Similar significant decreases in RDR with planting depth were observed in the cherries (Figure 2; Tables 1 and 3). Thus, deep-planted trees had far fewer roots in the upper soil layers than properly planted trees 1 full year after transplant.

The cherries had shallower root systems than the maples $(P<0.0016$; Tables 1 and 3$)$ : cherry RDR averaged $2.57 \pm$ 2.34 across all treatments and distances, whereas maple RDR averaged $1.51 \pm 1.57$.

\section{Girdling Root Development}

In January 2000, root collar excavations revealed that deep planting had a significant impact on girdling root development in the red maples (Figures 3 and 4). Control maples had $14 \% \pm 19 \%$ of their trunk circumference encircled by girdling or potentially girdling roots; this number rose to $48 \% \pm 29 \%$ and $71 \% \pm 21 \%$ for $15 \mathrm{~cm}$ (6 in) and $31 \mathrm{~cm}$ (12 in) deepplanted maples, respectively. There were no treatment-related differences in girdling root development in the cherries.

\section{DISCUSSION}

Deep planting by as little as six in had serious consequences for posttransplant survival in Yoshino cherry and girdling root development in red maple. Within 2 years of transplanting, half of the deep-planted cherries had died; within 3 years of transplanting, the deep-planted maples had developed girdling roots around much of their trunk circumference. These results are consistent with arborists' observations that deep planting predisposes trees to transplant failure.

\section{Initial Deep-Planting Effects}

In most forest trees, the majority of fine roots are located in the top $15 \mathrm{~cm}$ (6 in) of soil where mineral nutrients and 


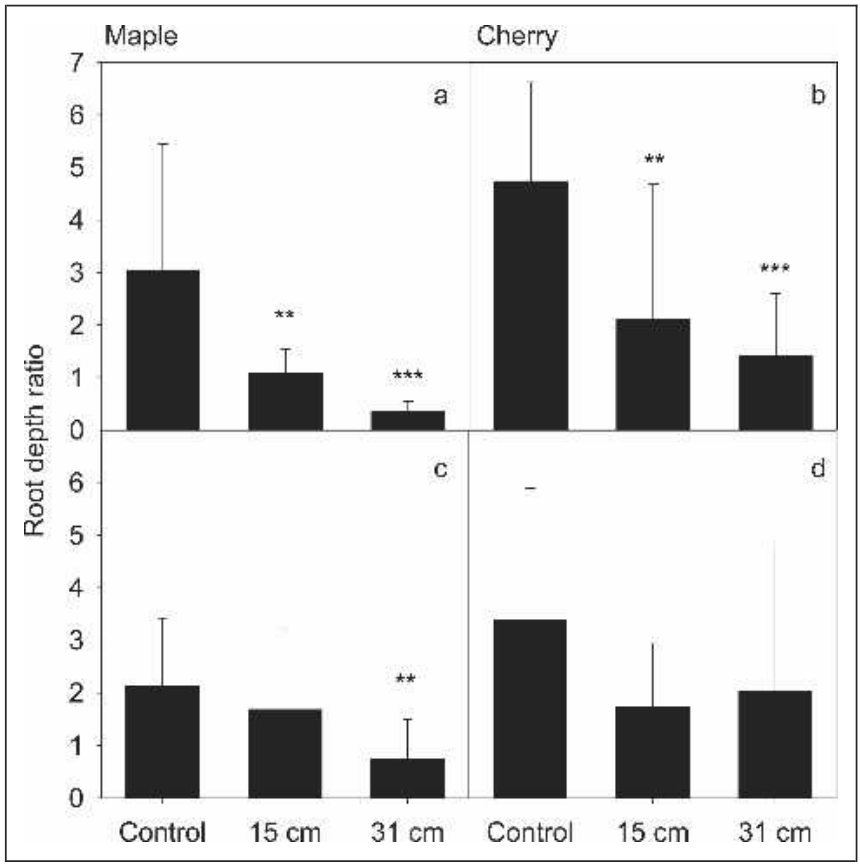

Figure 2. Root depth ratios of trees from control, $15 \mathrm{~cm}$ (6 in) deep-planted, and $31 \mathrm{~cm}$ (12 in) deep-planted treatment groups measured at distances of $15 \mathrm{~cm}$ (6 in) (top panels) and $41 \mathrm{~cm}$ (16 in) (bottom panels) from the stem base. The root depth ratio is defined as the root mass density $\left(\mathrm{g} / \mathrm{cm}^{3}\right.$ soil) in the upper $30.5 \mathrm{~cm}$ (12 in) of soil divided by the root mass density in the lower 30.5 to 61 $\mathrm{cm}$ (12 to 24 in) of soil (see "Methods"). Within a panel, bars marked with an asterisk are significantly different from control $\left({ }^{*} P<0.05\right.$; ${ }^{* *} P<0.01$; ${ }^{* * *} P<0.001$; mean separations performed using Tukey's HSD).

rainfall are most abundant (Kozlowski and Pallardy 1997). At greater soil depths, oxygen partial pressures may also fall below those needed to support root respiration, growth, and nutrient uptake (Kozlowski 1985; but see MacDonald et al.

Table 3. Effect of planting depth treatment $(0,15$, or 31 $\mathrm{cm}(0,6$, or 12 in) deep-planted), distance from the trunk (15 or $41 \mathrm{~cm}$ (6 or 16 in)), and species (maple or cherry) on the root depth ratio (RMD in top $30 \mathrm{~cm}$ (12 in) of soil/RMD in 30 to $60 \mathrm{~cm}$ (12 to 24 in) soil depth) ${ }^{2}$.

\begin{tabular}{llrr}
\hline Source & DF & F Value & Pr $>$ F \\
\hline Treatment & 2 & 17.19 & $<0.0001$ \\
Distance & 1 & 0.27 & 0.6020 \\
Treatment*distance & 2 & 2.35 & 0.1006 \\
Species & 1 & 10.47 & 0.0016 \\
Treatment*species & 2 & 0.76 & 0.4693 \\
Distance*species & 1 & 0.38 & 0.5395 \\
Treatment*distance*species & 2 & 0.29 & 0.7514 \\
\hline
\end{tabular}

\footnotetext{
${ }^{\mathrm{z}}$ Measurements were taken in December 1997, 1 year after transplanting.
}

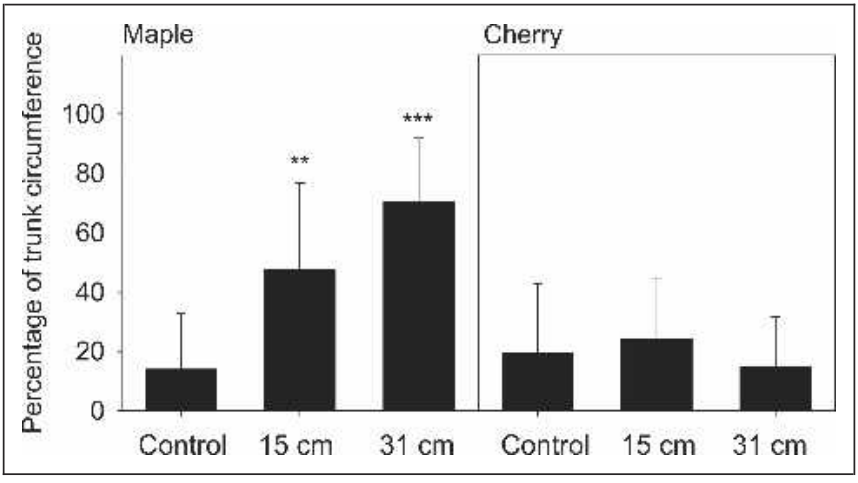

Figure 3. Mean percentage of the trunk circumference encircled by girdling and potentially girdling roots in trees from control, $15 \mathrm{~cm}$ ( $6 \mathrm{in}$ ) deep-planted, and $31 \mathrm{~cm}$ (12 in) deep-planted treatment groups. Within a panel, bars marked with an asterisk are significantly different from control $\left({ }^{* *} P<0.01 ;{ }^{* * *} P<0.001\right.$; mean separations performed using Tukey's HSD).

2004). The root balls of deep-planted trees in our study were placed below the top $15 \mathrm{~cm}$ (6 in) of soil at the time of transplant. However, only the cherries exhibited visual symptoms and significant tree mortality in response to deep planting.

The nature of the initial stress associated with deep planting in our study is not known. Although we did not measure oxygen partial pressures in the soil, the site characteristics lead us to suspect that flooding and anoxia may have played an important role. The site exhibited a 10\% slope, and, after heavy rain events, runoff and pooling of water in the lower portions of the site was observed. Although the effect of slope

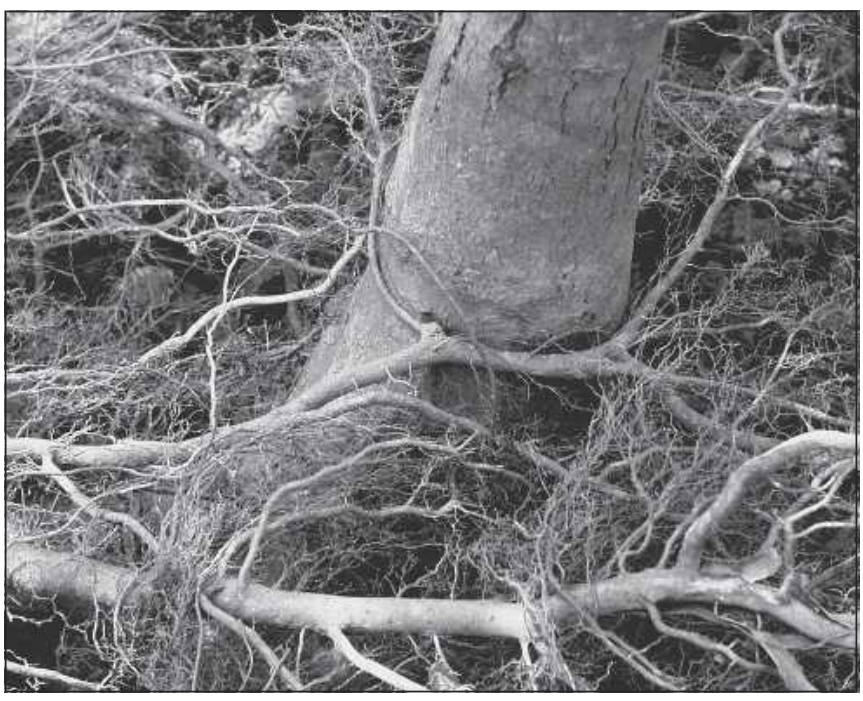

Figure 4. Girdling root development in a red maple planted with the root flare $15 \mathrm{~cm}$ (6 in) below grade. 
position on cherry survival was not statistically significant, there was a trend toward greater mortality on the lower portions of the site (data not shown). It is also suggestive that the majority of cherry deaths occurred in 1998 after a particularly wet early Spring.

In flooded or waterlogged soils, aerobic conditions may extend only a few centimeters beneath the soil surface (Taiz and Zeiger 2002). Under such conditions, trees with the majority of their root system below $15 \mathrm{~cm}$ (6 in) would be subjected to severe anoxia. Yoshino cherry, in particular, is known to be intolerant of flooding (Rowe and Beardsell 1973; Jacobs and Johnson 1996). Nonetheless, we cannot rule out other mechanisms of deep planting stress such as reduced water infiltration to the root ball or insufficient access to shallow mineral nutrient pools.

Infection by pathogenic fungi such as Phytophthora is encouraged under flooded or poorly drained conditions (Wilcox 1993). However, tests at our site showed no relationship between treatment or slope position and the sporadic incidence of Phytophthora infection in the planting (data not shown). It is therefore unlikely that enhanced Phytophthora infection was the proximate cause of deep-planting stress.

An interesting comparison can be made between our results and those of MacDonald et al. (2004), also working with Yoshino cherry. In their study, the addition of $30 \mathrm{~cm}$ (12 in) of fill soil over the root zones of established cherries had no effect on soil aeration or tree performance. This result suggests that root collar burial, in and of itself, may not cause stress under all conditions.

A potentially important difference between our study and that of MacDonald et al. (2004) concerns the initial condition of the plant material: trees in the MacDonald study had been growing in situ for 3 years, whereas those in our study had recently been dug for transplant. Balled-and-burlapped trees lose a significant fraction of their fine root system at transplant, and the trees in our study therefore experienced root loss and root system burial simultaneously. The combination of these stresses was likely more stressful than root system burial alone, as suggested by the differences in root growth between our study and that of MacDonald et al. At our site, deep-planted trees showed extremely limited root regrowth into the upper soil layers 1 year after transplant, whereas in the MacDonald study, the trees produced a substantial number of new roots in the upper fill soil.

Maples were better able to tolerate deep planting than cherries in the short term. Surprisingly, this greater tolerance was not related to more rapid reestablishment of a normal root depth distribution. One full year after transplant, the root distribution of the deep-planted maples was not different from that of deep-planted cherries and was still strongly skewed toward the lower soil profile. However, two other factors may have enhanced maple deep-planting tolerance. First, the maples produced significantly more roots than the cherries: their root mass densities were nearly twice as large. Therefore, although they did no better than the cherries in reestablishing a normal root depth distribution, they did have a larger absolute mass of roots in the upper soil layers. This additional shallow root mass may have allowed them better access to critical, shallow distributed soil resources. It is also possible that red maples had more effective physiological mechanisms of anoxia tolerance such as aerenchyma formation, efficient anaerobic metabolism, and antioxidant defenses after reaeration.

\section{Potential Long-Term Effects}

Although the maples appeared to tolerate deep planting in the short term, air spade excavations indicated that deep planting may have set the stage for future problems with stem-girdling roots. It is unclear why deep planting should predispose trees to girdling root formation. Stem-girdling roots are known to form at transplant when lateral root growth is stimulated by the severance of major structural roots radiating from the stem base (Watson et al. 1990). This effect is particularly pronounced in maples whose laterals tend to emerge at right angles to their parent roots. Roots that grow vertically toward the soil surface after deep planting may be more likely to assume a girdling orientation, particularly if they tend to grow along the oxygen-rich interface between the deeply planted trunk and the bulk soil.

Conflicting observations have been published on the potential link between deep planting and girdling root formation. In a series of root collar excavations on maples, Watson et al. (1990) found no relationship between planting depth and girdling root formation. However, recent work by Johnson and Hauer (2000) suggests that such a relationship exists in some species. Our work represents the first time that the effects of deep planting on girdling root formation have been tested experimentally.

Although deep-planted maples showed substantial girdling root development, it is not yet clear whether these girdling roots will persist and cause long-term damage to the trees. Serious symptoms of girdling root injury do not appear in Norway maple until the trees approach 8 to 10 in (20 to 25 $\mathrm{cm}$ ) caliper (Gouin 1984), and it therefore may be many years before the girdled red maples at our site exhibit reductions in growth or vigor. Furthermore, there is evidence to suggest that girdling roots of red maple, although numerous after transplantation, may not persist long enough to cause serious damage (Watson et al. 1990). Follow-up measurements at our site will shed light on the degree to which early girdling root formation causes long-term injury in red maple.

In conclusion, our results support the hypothesis that deep planting can predispose trees to transplant failure and girdling root formation. Although the effects of deep planting will certainly vary with species and site conditions, the few extra minutes needed to identify a tree's root collar and place it at 
grade could mean the difference between its survival and failure in the landscape.

Acknowledgments. The authors thank the Tree Research and Education Endowment Fund for their support of this research and Dr. Edward Gilman for valuable discussion of the results. Two anonymous reviewers provided helpful

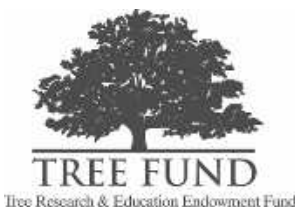
suggestions for improvement. Technical assistance was provided by Kristen Colvin and Alicia Wood.

\section{LITERATURE CITED}

Broschat, T. 1995. Planting depth affects survival, root growth, nutrient content of transplanted pygmy date palms. HortScience 30:1031-1032.

Gilman, E.F., and J. Grabosky. 2004. Mulch and planting depth affect live oak establishment. Journal of Arboriculture 30:311-316.

Gouin, F.R. 1984. Girdling roots, fact or fiction. Combined Proceedings of the International Propagators Society 33: 428-432.

Jacobs, K.A., and G.R. Johnson. 1996. Ornamental cherry tolerance of flooding and Phytophthora root rot. HortScience 31:988-991.

Johnson, G., and R. Hauer. 2000. A Practitioner's Guide to Stem Girdling Roots of Trees. University of Minnesota Extension Publication BU-7501-S.

Kozlowski, T.T., and S.G. Pallardy. 1997. Physiology of Woody Plants, 2nd ed. Academic Press, San Diego, CA.

MacDonald, J.D., L.R. Costello, J.M. Lichter, and D. Quickert. 2004. Fill soil effects on soil aeration and tree growth. Journal of Arboriculture 30:19-26.

Maynard, B.K. 1995. A problem of great depth ... some nursery production practices may be leading to trees being planted too deeply. Yankee Nursery Quarterly 5:1-4.

Rowe, R.N., and D.V. Beardsell. 1973. Waterlogging of fruit trees. Horticultural Abstracts 43:533-548.

Smiley, E.T., and D.C. Booth. 2000. Grown to die. American Nurseryman 191:48-54.

Taiz, L., and E. Zeiger. 2002. Plant Physiology, 3rd ed. Sinauer Associates, Inc., Sunderland, MA.

Watson, G.W., S. Clark, and K. Johnson. 1990. Formation of girdling roots. Journal of Arboriculture 16:197-202.

Wilcox, W.F. 1993. Incidence and severity of crown and root rots on four apple rootstocks following exposure to Phytophthora species and waterlogging. Journal of the American Society for Horticultural Science 118:63-67.

Christina Wells (corresponding author)

Assistant Professor

Department of Horticulture

Clemson University

Clemson, SC 29634 U.S.

cewells@clemson.edu
Karen Townsend

Graduate Researcher

Department of Horticulture

Clemson University

Clemson, SC 29634 U.S.

Judy Caldwell

Associate Professor

Department of Horticulture

Clemson University

Clemson, SC 29634 U.S.

Donald Ham

Professor Emeritus

Department of Forestry and Natural Resources

Clemson University

Clemson, SC 29634 U.S.

E. Thomas Smiley

Arboricultural Researcher

Bartlett Tree Research Laboratories

13768 Hamilton Road

Charlotte, NC 28217 U.S.

Michael Sherwood

Research Associate

Bartlett Tree Research Laboratories

13768 Hamilton Road

Charlotte, NC 28217 U.S.

Résumé. Les arbres ornementaux sont fréquemment plantés avec leur collet racinaire sous le niveau du sol, une pratique qui prédispose ces derniers à un échec de leur transplantation en plus de permettre la formation de racines strangulantes. L'objectif de la présente recherche était d'examiner l'effet de la profondeur de plantation sur la santé, la survie et le développement des racines chez deux espèces populaires d'arbres ornementaux, l'érable rouge (Acer rubrum) et le cerisier de Yedo (Prunus $\times$ yedoensis). Les arbres ont été transplantés avec leur collet au niveau du sol ainsi qu'à 15 et 31 $\mathrm{cm}$ sous le niveau du sol. La plantation en profondeur diminuait le taux de survie des cerisiers de Yedo: 2 ans après la transplantation, $50 \%$ des arbres plantés à 15 et $31 \mathrm{~cm}$ de profondeur étaient morts tandis que tous les cerisiers plantés avec le collet au même niveau que le sol avaient survécus. Le taux de survie des érables n'était pas affecté par la profondeur de plantation. La profondeur de plantation avait aussi une influence sur la présence de racines strangulantes. Trois ans après la transplantation, les érables plantés avec le collet au même niveau que le sol avaient $14 \%$ de la circonférence de leur tronc encerclé par des racines strangulantes ou potentiellement strangulantes; ce nombre augmentait à $48 \%$ et $71 \%$ pour les arbres plantés à respectivement $15 \mathrm{~cm}$ et $31 \mathrm{~cm}$ sous le niveau du sol. Il n'y avait pas de différence entre les diverses profondeurs de plantation en regard du développement de racines strangulantes dans le cas des 
cerisiers. Ces résultats sont conformes aux observations des arboriculteurs à l'effet que la plantation en profondeur constitue une source significative de stress pour les arbres ornementaux.

Zusammenfassung. Landschaftsbäume werden gelegentlich mit ihrem Wurzelkragen eingegraben, eine Praxis, die zur Bildung von Würgewurzeln und frühem Absterben führen kann. Das Ziel dieser Untersuchung lag in der Erforschung der Auswirkung der Pflanztiefe auf die Gesundheit, Überleben und Wurzelentwicklung von 2 beliebten Landschaftsbäumen, Acer rubrum und Prunus $\times$ yedoensis. Die Bäume wurden verpflanzt mit ihrer Wurzelfläche auf Level, und $15 \mathrm{~cm}$ resp. $30 \mathrm{~cm}$ unter Level. Das tiefe Pflanzen reduzierte das Überleben von der Kirsche: 2 Jahre nach der Verpflanzung waren $50 \%$ der Pflanzen bei $15 \mathrm{~cm}$ und $30 \mathrm{~cm}$ abgestorben, wobei alle Kirschen, die auf Bodenlevel gepflanzt wurden, überlebt hatten. Das Überleben der Ahorne wurde durch die Pflanztiefe nicht beeinflusst. Das tiefe Pflanzen hatte auch Einfluss auf die Bildung von Würgewurzeln. Drei Jahre nach d Verpflanzung hatten die auf Level gepflanzten Ahorne 14\% ihres Stammumfangs mit Würgewurzeln oder Vorstadien davon umwachsen. Diese Zahl stieg auf $48 \%$ und $71 \%$ bei $15 \mathrm{~cm}$ rep. $30 \mathrm{~cm}$ Tiefe. Es gab keine relevanten Unterschiede bei der Bildung von Würgewurzeln bei den Kirschen. Diese Resultate stimmen überein mit den Beobachtungen der Arboristen, dass die Pflanztiefe eine bedeutende Stressquelle für Bäume darstellt.
Resumen. Los árboles ornamentales son frecuentemente plantados con sus coronas de raíces debajo del nivel del suelo, una práctica que puede predisponerlos a fallas y formación de raíces estranguladoras. El objetivo de la presente investigación fue examinar el efecto de la profundidad de plantación en la salud, supervivencia y desarrollo de raíces en dos árboles ornamentales populares, maple rojo (Acer rubrum) y cerezo Yoshino (Prunus $\times$ yedoensis). Los árboles fueron trasplantados con sus raíces superficiales a nivel, a $15 \mathrm{~cm}$. (6 pulg) debajo del nivel o $31 \mathrm{~cm}$. (12 pulg) debajo del mismo. La plantación profunda redujo la supervivencia de los cerezos Yoshino: dos años después del trasplante; $50 \%$ de los cerezos plantados a 15 $\mathrm{cm}$. y $31 \mathrm{~cm}$. de profundidad habían muerto, mientras que todos los cerezos plantados a nivel habían sobrevivido. La sobrevivencia de los maples no fue afectada por la profundidad de plantación. La profundidad de plantación también influyó en el desarrollo de raíces estranguladoras. Tres años después del trasplante, los maples plantados a nivel tuvieron $14 \%$ de su circunferencia del tronco estrangulada por las raíces; este número se elevó a $48 \%$ y $71 \%$ para los maples plantados a $15 \mathrm{~cm}$. y $31 \mathrm{~cm}$. de profundidad, respectivamente. No hubo diferencias en el desarrollo de las raíces estranguladoras en los tratamientos con los cerezos. Estos resultados son consistentes con las observaciones de los Arboristas de que la plantación profunda es una fuente significativa de estrés en los árboles ornamentales. 